\title{
LRMSC Grade 1, Subcutaneous Tissue
}

National Cancer Institute

\section{Source}

National Cancer Institute. LRMSC Grade 1, Subcutaneous Tissue. NCI Thesaurus. Code C121176.

Slight induration (fibrosis) and loss of subcutaneous fat. 